\title{
AN INTERPRETATION OF THE ACT OF I939 (FELA) TO SAVE SOME REMEDIES FOR COMPENSATION CLAIMANTS
}

\author{
Vernon X. Miller*
}

In recent years the story of FELA has been told often. ${ }^{1}$ It is not necessary to repeat much of it here except by way of summary. For I906 and I908 the Federal Employers' Liability Act was a remedial scheme. ${ }^{2}$ Understandably in those years lawmen looked skeptically at social legislation. The dead hand of a pre-industrial society was being pulled from the eighteenth century through the Fourteenth Amendment to choke state welfare programs. ${ }^{3}$ Some lawyers in Igo8 were prepared to argue that judge-made concepts like fellow-servant, contributory negligence, and fault are comparable to dogmatic truths." Nevertheless, when the chips were down, even a tough constitutionalist like Van Devanter was not convinced. ${ }^{5}$ He remembered Waite's epigram that there is no vested interest in a rule of law. ${ }^{6}$

It was a unanimous Court, speaking through Van Devanter, that approved the second Federal Employers' Liability Act. The statute was a regulation of commerce within the delegated powers of Congress, the Court said, and the scheme of it was consistent with due process, although Congress had dared to touch contributory negligence and fellow-servant and to regulate the employment relations between interstate railroads and their workmen. In the Second Act of Ig08 Congress respected

*A.B. 1923, LL.B. 1925, University of Minnesota; J.S.D. I929, Yale University. Member of the Minnesota and Wisconsin bars; Dean and Professor of Law, University of San Francisco, since 195r. Member of the Council, Louisiana State Law Institute, 1942-1951. Author, Workmen's Compensation for Railroad Employees, 2 Loyola L. REv. 138 (1944). Contributor to legal periodicals.

${ }^{1}$ See the symposium in a recent volume of the Cornell Law Quarterly. Pollack, Workmen's Compensation for Railroad Work Injuries and Diseases, 36 ConNel. L. Q. 236 (195I); Richter and Forer, Federal Employers Liability ACt-A Real Compensatory Law for Railroad Workers, 36 CoRNell. L. Q. 203 (195I). See also Delisi, Federal Employers Liability Act-Scope and Recent Developments, r8 Miss. L. J. 206 (1947); Miller, Workmen's Compensation for Railroad Employees, 2 LoyoLA L. Rev. 138 (I944). The most important publication in the field is the Survey of the United States Railroad Retirement Board published in 2947 , WORK INJURIES IN THE R'AILROAD INDUSTRX I938-I940, in two volumes [hereinafter referred to as RRB SuRver].

2 The First Federal Employers' Liability Act was approved on June II, I906. 34 Stat. 232. The Supreme Court decided that the first statute was unconstitutional. The criticism was special and it is discussed below in the text. See The Employers' Liability Cases, 207 U. S. 463 (1908). The Second Act was approved on April 22, 1908. 35 STAr. 65. See 45 U. S. C. $\$ 5$ I et seq. (1946).

${ }^{3}$ It is a big order to cite cases for this proposition. You think of Mr. Justice Field and freedom of contract and you think of lawyer Campbell after he retired from the bench and his arguments on privileges and immunities and due process. Perhaps the one case that illustrates best the figure of speech in this proposition is Lochner v. New York (198 U. S. 45) decided in rgo5.

'See the arguments of the railroads' counsel summarized in the report of the First Cases. 207 U. S. at 484-485. See the argument of John H. Hall for the railroads in the Second Cases, 223 U. S. at 4r.

"The Second Act was approved by the Supreme Court in 19r2. Second Employers' Liability Cases, 223 U. S. I (19.12).

'See Van Devanter, J., in 223 U. S. at 50; cf. Waite, C. J., in Munn v. Illinois, 94 U. S. I13, 134 $(1876)$. 
the Supreme Court's judgment; ${ }^{7}$ the regulating of employment was restricted to instances occurring in interstate commerce. But Congress did not dare to touch the fault concept in the First Act of 1906 or in the Second Act in 1908, nor has Congress dared to touch it up to now. Although there are many other chapters in this story, that one is vital; work injury claims in the railroad business are adjusted like other torts.

Many lawmen in $x 953$ will describe any such program for settling work injuries as obsolete. They think workmen's compensation is a better system, and they think also that they have the experiences of forty years to corroborate their opinions. Now these lawmen are told that compensation is a costly scheme, that administrative expenses are high, that awards are inadequate, and that there is quantity litigation developing from questioned claims. ${ }^{8}$ Facts and figures are produced to show that railroad men on the average and railroad employers on the average are better off under the remedial tort scheme of the Federal Act than they would be under compensation schemes in comparable areas. It is argued from the data in these compilations that lawyers' costs are greater under compensation programs, that settlements are easier under the Federal Act, and that the costs to carriers under it are relatively moderate. But some lawmen are skeptical of figures. Even in simple cases, they think the fault standard is an artificial one. They are not sure that fault can ever be an adequate measure of a person's social responsibilities in the intricate society of the mid-twentieth century. About FELA they know the story is a special one, that percentagewise more plaintiffs will get judgments in these cases than in the ordinary lawsuits for simple torts. But they know also that all plaintiffs do not win even under this statute and that big verdicts and judgments are not always good for everyone. Perhaps big judgments are not too large for plaintiffs' needs and lawyers' work, ${ }^{9}$ but they can drain the resources of defendants who must pay the judgments. There is a law of diminishing returns; the employment relation cannot be charged with all the social costs of work hurts.

Although the fault concept is vital in the story of FELA, it is not the only important chapter. How the Court in the early days limited the special statutory scheme to cases affecting transportation or something so closely connected with it as to be practically a part thereof is a chapter in the story that delights legalistic lawmen. ${ }^{10}$ That tight transportation test was a common-law lawyer's kind of device to stimulate appeals and spark litigation. It was pinpointed, as the New York courts describe it, to the occasion of the injury. ${ }^{11}$ How the Court developed the

\footnotetext{
'See the decision on the First Act. The Employers' Liability Cases, 207 U. S. 463 (1908), discussed in the text.

${ }^{8}$ See the pilot study prepared by authorization of the Graduate College, University of Illinois, under the direction of Professors Alfred F. Conard and Robert I. Mehr: Costs of Administering Reparation FOR WORK INJURIEs In IluinoIs (1952). See also Conard, Workmen's Compensation: Is It More Efficient than Employer's Liability?, 38 A. B. A. J. IorI (1952). Cf. Richter and Forer, Federal Employers' Liability Act-A Real Compensatory Law for Railroad Workmen, 36 CoRNel. L. Q. 203 (1951).

'See Editorial, 5 NACCA L. J. I I (1950); Note, 4 id. at 280-3 10 (rg49).

${ }^{10}$ Shanks v. Delaware, Lack. \& West. R. R., 239 U. S. 556 (I9x6). (1949).
} 
distinction between assumption of risk and contributory negligence so that one was an absolute defense in spite of the statutory text and the other sufficient only to affect the quantity of compensation is another chapter to intrigue the lawyer with little taste for sociology. ${ }^{12}$ How all of this was developed by the Court while state compensation programs were expanding to absorb some of the left-overs, even among railroad workmen, ${ }^{13}$ is a chapter the legalists would like to overlook were it not for New York Central Railroad v. Winfield..$^{14}$ The lawyers' Court that developed the transportation test and the fine distinction between contributory negligence and assumption of risk declared in Winfield that they would protect the regulatory scheme for railroad workmen against state compensation. The Act of Congress was exclusive whenever a claim could be litigated under the Federal Act. That was the Court's interpretation although Congress had not prescribed so by specific text. Nevertheless, as the courts weeded out ${ }^{15}$ more cases from the Federal Act through the transportation and pinpoint tests, a few more cases fell to workmen's compensation until Congress plugged the leak in I939. ${ }^{16}$

Did Congress try to reduce the compensation area in I939? If you count noses among judges the score is lopsided. ${ }^{17}$ Because the federal scheme can be exclusive if Congress wants to make it so, and because the Court said in the Winfield case that Congress must have so intended, almost all of the men who have sat in judgment have said that Congress tried to plug the leak. The Illinois Supreme Court has held otherwise. ${ }^{18}$ Some other judges have agreed with the Illinois court, notably

${ }^{12}$ See Toledo, St. L. \& W. R. R. v. Allen, 276 U. S. 165 (1928); Delaware, Lack., \& West. R. R. v. Koske, 279 U. S. 7 (1929). In these cases the Supreme Court confirmed the case law of the lower courts. In the Koske case Mr. Justice Butler said (p. II): "Defendant was not bound to maintain its yard in the best or safest condition; it had much freedom in the selection of methods to drain its yard and in the choice of facilities and places for the use of its employees. Courts will not prescribe standards in respect of such matters or leave engineering questions such as are involved in the construction and maintenance of railroad yards and the drainage system therein to the uncertain and varying judgment of juries!"

${ }_{13}$ Sec Miller, Workmen's Compensation for Railroad Eniployees, 2 Loyola L. Rev. 138, 152 (1944).

${ }^{14} 244$ U. S. 147 (1917). There is another Winfield case published in the same volume. The plaintiffs are not the same Winfields and the events in the two cases are not related. See Erie R. R. v. Winfield, 244 U. S. 170 (1917).

${ }^{16}$ In I910 Congress provided specially that state and federal courts should have concurrent jurisdiction in these cases. 36 Stat. 29r, as amended in 1948,62 STAT. 989 . See 45 U. S. C. \$56. In effect the plaintiffs may choose the courts for trial. State legislatures have tried to reduce the trying of cases affecting non-residents and out-of-state events in local courts. See Baltimore \& Ohio R. R. v. Kepner, 3 I4 U. S. 44 (I94I). This kind of legislation can be supported now if it is effective against all nonresidents including those who are domiciled in the local state. Missouri v. Mayfield, 340 U. S. I (I950).

${ }^{10}$ See Miller, Workmen's Compensation for Railroad Employees, 2 LoyouA L. Rev. 138, I52-153 (1944); RRB Sunvex 8, 28.

${ }_{17}$ The list of cases in which compensation was denied is long. Kettner v. Industrial Comm., 258 Wis. 6r5, 46 N. W. 2d 833 (r95r); Bowers v. Wabash R. R., 246 S. W. 2d 535 (Mo. App. 1952); Baird v. New York Central R. R., 299 N. Y. 213,86 N. E. 2d 567 (I949); Trucco v. Erie R. R., 353 Pa. 320, 45 A. 2d 20 (I946), confirming the decision in Scarborough v. Pennsylvania R. R., 154 Pa. Super. I29, 35 A. 2d 603 (r944); Albright v. Pennsylvania R. R., I93 Md. 421, 37 A. 2d 870 (r944); Prader v. Pennsylvania R. R., II3 Ind. App. 518, 49 N. E. $2 d 387$ (I943); Southern Pac. Co. v. Industrial Acc. Comm., rg Cal. 2d 27I, I20 P. 2d 880 (I942); Piggue v. Baldwin, I54 Kan. 708, I2I P. 2 I I83 (I942); Louisville \& N. R. R. v. Potts, I78 Tenn. 425, I58 S. W. $2 d 729$ (I942).

${ }_{18}$ Thomson v. Industrial Commission, 380 Ill. 386,44 N. E. $2 d$ I9 (1942), discussed in 2 Lorous L. REv. 93 (r943). 
some of the judges in the appellate divisions in New York ${ }^{10}$ and the judges of the Supreme Court of Idaho, ${ }^{20}$ but the Court of Appeals in New York has added its weight to the majority side, ${ }^{21}$ and the judges in Idaho depended much on case law from the old regime. ${ }^{22}$ The judges of the Supreme Court in South Carolina will be on the Illinois side when the right case comes along, because they have said already that Congress has not foreclosed the deciding of some railroad cases under a state employers' liability act. ${ }^{23}$ Perhaps it is significant that the Supreme Court has refused to commit itself, although it has supervised carefully the administering of the statute as amended in every other area. Perhaps it is significant also that Winfield was decided in rigr.

The year 1939 was a milestone in the story of the Federal Act. The statute was amended, ${ }^{24}$ the rigid transportation test for interstate commerce was rejected, and assumption of risk was classified with contributory negligence. Interstate commerce was expanded to include more than transportation, and the scheme of the statute was extended to cover work injuries happening to anyone, any part of whose duties are in furtherance of such commerce. The old distinctions in the case-law results had seemed artificial to many lawyers. ${ }^{25}$ From the story of the litigation in the years before 1939, from the discussions in the houses of Congress, and from the text of the statute as amended, one deduction seems obvious. Congress was trying to cure a bad situation. Congress was trying to rescue the Court from legalisms that were sterile. The transportation test was devised by the Court within a few years after the date of the adverse decision on the first Federal Act. ${ }^{26}$ Under the commerce clause the Court had said in that first case that Congress could regulate only those injuries that were suffered by railroad men who were engaged in interstate commerce when they were hurt. ${ }^{27}$ If that premise is true, the pinpoint test for transportation does have meaning. However, during the years between 1908 and 1939 the Court in other

${ }^{10}$ See Heffernan, J., dissenting in Wright v. New York Central R. R., 263 App. Div. 461, 462, 33 N. Y. S. 2d 531, 532 (3d Dep't 1942); Baird v. New York Central R. R., 274 App. Div. 577, 86 N. Y. S. 2d 54 (3d Dep't r948).

${ }_{20}$ Moser v. Union Pac. R. R., 65 Ida. 479, I47 P. $2 d 336$ (1944).

${ }^{21}$ Baird v. New York Central R. R., 299 N. Y. 213, 86 N. E. 2d 567 (1949), reversing Baird v. New York Central R. R., 274 App. Div. 577, 86 N. X. S. 2d 54 (3d Dep't 1948).

${ }_{22}$ The Idaho court was willing to sacrifice some of the new statutory program to save a little bit of workmen's compensation. The injured man was working on a new construction project. Under the transportation test of the older case law that was not interstate commerce. $C f$. New York Central R: R. v. White, 243 U. S. 188 (I917) (the first compensation case). It has been argued and decided that this kind of work does pertain to the furtherance of commerce under the new definition. Agostino v. Pennsylvania R. R., 50 F. Supp. 726 (E. D. N. Y. 1943); cf. Note, I53 A. L. R. 357 (1944). The Idaho workman did not have a case for tort. After suffering a severe pain in his back he had collapsed on the job and he was injured as he fell. It was a typical compensation case under the old case law which the court relied on here without considering how the decision might affect the case of another workman injured on a job like this where he might have a cause of action for fault.

${ }_{23}$ Boyleston v. Southern Ry., 2 I I S. C. 232,44 S. E. $2 d 537$ (1947).

24 Act of August XI, 1939, 53 STAт. x404; 45 U. S. C. \$5I et seq. (1946).

${ }^{25}$ See Hearings before a Subcommittee of the Senate Iudiciary Committee on S. 1708 (Amending the FELA), 76th Cong., Ist Sess. (1939). The general counsel of the American Association of Railroads agreed with the general counsel for the Brotherhood of Railroad Trainmen. See particularly, id. at 24-25.

${ }_{20}^{20}$ Shanks v. Delaware, Lack. \& West. R. R., 239 U. S. 556 (1916).

27 The Employers' Liability Cases, 207 U. S. 463 (I908). 
cases touching other fields had gone far to agree with Congress that regulatory powers over commerce are great enough to affect not only the carrying and selling of goods in commerce but even the steps preliminary to the production of goods for interstate commerce. ${ }^{28}$ There is little if anything in the history of previous litigation, in the floor discussion, or in the text of the statute to support a deduction that Congress was trying to close a gap and to shut off all other possible remedies, unless it is found in the Winfield case and the silence of Congress.

The other big remedial change of 1939 affected assumption of risk. Distinguishing between a plaintiff's assuming the risk of injury and contributing to his hurt through his own misconduct often is a matter of literal explanation. The case law in this area before 1939 was difficult to accept, ${ }^{29}$ and Congress abolished the distinction. Obviously Congress was not trying to close a gap with this proposal. Many persons who would have been barred under the old defense have been successful as plaintiffs because of this change in the statute, ${ }^{30}$ and the Court has been careful to protect these plaintiffs against a new kind of playing with the old defense. It is not a risk of railroading which a workman must accept, when a condition exists that the company can reduce..$^{31}$ Proof of that condition is enough to support a plaintiff's prima facie case of fault. ${ }^{32}$

Most of what has happened since 1939 has been good. The old statute was inadequate and the case-law distinctions were artificial. The Act of 1939 was good social legislation, and the courts have been generous in appraising the new standards. ${ }^{33}$ There has been some lawyer criticism of the newer case-law trends, as if

${ }^{28}$ The Wagner Act: 49 Srat. 449 (1938); Labor Board v. Jones \& Laughlin, 30 I U. S. I, 34 (I937); Santa Cruz Co. v. Labor Board, 303 U. S. 453 (I938). The Fair Labor Standards Act: 52 Stat. I060 (1938); United States v. Darby, 3 I2 U. S. 100 (I94I); Kirschbaum Co. v. Walling, 3I6 U. S. 5I7 (1942). The decisions under the Fair Labor Standards Act were effected after 1939 but the statute was enacted in $193^{8}$ and the favorable opinions of 1941 and 1942 were generated in the case law of r937 and 1938 .

${ }^{20}$ See the cases cited in note 12, supra. See Snow v. Texas \& P. Ry., I66 So. 200 (La. App. I936). The decedent's dependents were denied relief although some of the dead man's colleagues were tortfeasors. The decedent knew he could not swim when he stepped onto an unstable raft in a pond of water.

${ }^{30}$ See Wilkerson v. McCarthy, 336 U. S. 53 (r948); Sadowski v. Long Island R. R., 292 N. Y. 448, 55 N. E. 2d 497 (15944).

${ }^{31}$ Tiller v. Atlantic Coast Line R. R., 318 U. S. 54 (1943). The plaintiff in the Tiller case had to wait long to get justice in the end. See Tiller v. Atlantic Coast Line R. R., 323 U. S. 574 (1945). Again the court of appeals was reversed, but this time a jury had found a verdict for the plaintiff and the case was remanded for judgment to be entered on the verdict.

${ }^{32}$ Cf. Fleming v. Kellett, 167 F. 2d 265 (roth Cir. I948).

${ }^{33}$ We are thinking here of cases like Tiller on assumption of risk and of those cases in both state and federal courts where the judges have tried to reach with Congress for an expansive concept of interstate commerce. When the injured workman can build on fault, this generous interpretation produces good results. Cf. Edwards v. Baltimore \& O. R. R., I3I F. 2d 366 (7th Cir. 1942); Erwin v. Pennsylvania R. R., 36 F. Supp. 936 (E. D. N. Y. I94I); Maxies v. Gulf, M. \& O. R. R., 358 Mo. II90, 219 S. W. 2d 322, ro A. L. R. 2d 1273 (I949); Atlantic Coast Line R. R. v. Meeks, 30 Tenn. App. 520, 208 S. W. 2d 355 (1947); Missouri Pac. R. R. v. Fisher, 206 Ark. 705, 177 S. W. 2d 725 (1944). Perhaps all of the plaintiffs would have been denied relief in actions under the statute before I 939 because when they were hurt they were not engaged in interstate commerce, as it was defined in the Shanks case. However before 1939, persons like these plaintiffs could have qualified as claimants for state compensation. Unless the old compensation benefits have been preserved, men like these would be without relief today if they could not win on fault. 
the results indicate now that there is an absolute liability under this statute without the standardizing of compensation that is attendant usually with an absolute liability program..$^{34}$ These critics protest too much. It is true, as we have seen, that the courts have protected railroad workmen against a new kind of assumption-of-risk defense. It is true also that there are decisions like Tennant v. Peoria $\&$ Pekin Union Railroad ${ }^{35}$ and Bailey $v$. Central of Vermont Railway ${ }^{36}$ where the evidence was circumstantial or the omissions very slight. ${ }^{37}$ Perhaps the catalogue of cases where juries find on negligence against plaintiffs in these actions is not large, but there are such cases, ${ }^{\mathbf{3 8}}$ and the list is long where courts have dismissed complaints or directed verdicts for defendants when the evidence of negligence was not enough. ${ }^{30}$ The Tennant case and the Bailey case point to possibilities for circumstantial evidence that the Supreme Court in the I920's might have appraised as insufficient. ${ }^{40}$ The Court has become more jury conscious on contributory negligence; comparisons of fault are for the jury only to adjudge. ${ }^{41}$ Nevertheless, FELA smacks of tort liability. Findings must depend on facts even where the inferences suggest nonfeasances. ${ }^{42}$

${ }^{34}$ See Black, J., in Wilkerson v. McCarthy, 336 U. S. 53, 6r-62 (1949).

32 U. S. 29 (1944).

30 319 U. S. 350 (1943).

${ }^{37} \mathrm{Cf}$. the following cases from state courts: Hayes v. Wabash R. R., 360 Mo. 1223, 233 S. W. $2 \mathrm{~d} 12$ (1950); Williams v. New York Central R. R., 402 Ill. 494, 84 N. E. 2d 399 (r949); Sadowski v. Long Island R. R., 292 N. Y. 448, 55 N. E. 2 d 497 (r944). See Biggs, J., in Jacobs v. Reading Co., 130 F. 2d $6 \mathrm{I2}_{2}, 613$ (3d Cir. 1942). Judge Biggs refers to the special standards for negligence in the case law under the Federal Act.

${ }^{38}$ Tracy v. Terminal Ass'n, r7o F. 2d 635 (8th Cir. I948); Kraus v. Reading Co., 167 F. 2d 313 (3d Cir. 1948); Roberts v. United Fisheries Co., I4I F. 2d 288 (rst Cir. 1944), cert. denied, 323 U. S. 753 (r944). The last case was tried under the Jones Act but the standards for negligence under that statute are comparable with those under FELA.

${ }^{30}$ Atlantic Coast Line R. R. v. Craven, 185 F. 2 d I76 (4th Cir. 1950) (brakeman encumbered with lantern and lunchbox injured when he tried to crawl over a gondola car in a moving train); Mastrandrca v. Pennsylvania R. R., I32 F. 2d 318 (3d Cir. 1942) (crossing watchman killed when trying to prevent children's crossing intersection); Southern Ry. v. Mays, r92 Va. 68, 63 S. E. 2d 720 (r95r) (section hand on special duty as watchman killed while crossing in front of train); Camp v. Southern Ry, 232 N. C. 487 , 6r S. E. 2d 358 (r950) (section forcman injured as he slipped and fell while trying to climb into a freight car through an open door); Cowdrick v. Pennsylvania R. R., 132 N. J. L. 131, 39 A. 2 d 98 (1944), cert. denied, 323 U. S. 799 (r945) (bridge tender fell from shanty with no eyewitnesses); Cunningham v. Great Northern Ry., 73 N. Dak. 315, I4 N. W. 2d 753 (1944) (telegraph lincman struck down in a speeder on main track by passenger train when there was no evidence that train was not on schedule); Osment v. Pitcairn, 349 Mo. I37, r59 S. W. 2d 666 (1942), cert. denied, 317 U. S. 587 (I942), 320 U. S. 792 (1943) (switching crewman disabled by fellow employee in horseplay when there was no evidence to suggest that fellow servant's conduct could have been expected). This is just part of the list but these are sufficient to indicate that the absolute liability criticism is an over-statement.

${ }^{10}$ Chicago M. \& St. P. Ry. v. Coogan, 27r U. S. 472 (x926). Nevertheless even today there must be something in the circumstantial evidence sufficient to support a finding that relates the injury to fault. Cf. Cowdrick v. Pennsylvania R. R., r32 N. J. L. 13.1, 39 A. 2d 98 (1944), cert. denied, 323 U. S. 799 (1945).

i1 Wilkerson v. McCarthy is the classic case of recent years. 335 U. S. 53 (1949). See also Uric v. Thompson, 337 U. S. 196 (1949); Terminal R. R. Ass'n of St. Louis v. Scharb, 151 F. 2d 36r (8th Cir. 1945). But see Southern Ry. v. Mays [192 Va. 68, 63 S. E. 2d 720 (195I)] where the state court offered as one reason for reversing the judgment on a verdict for the plaintiff that the accident was caused by the plaintiff's foolhardiness.

${ }^{12}$ In the Tennant case there was evidence that the trainman had not rung a warning bell. $C f$. Malone v. Gardner, 242 S. W. 2d 5 I6 (Mo. 195I) (where decedent fell from switch engine when no one was looking and where it was evident that the engine could have been equipped to reduce danger 
Although the courts have been generous in appraising the new statute and applying its standards to produce more judgments for successful plaintiffs, they have stubbed their toes in one small area. It is understandable but unfortunate that in the area of workmen's compensation judges have let the Winfield case spoil the remedial effects of the 1939 amendments. The Winfield case must be studied in its setting. Several important compensation cases were decided by the Supreme Court during the I9r6 Term, and Winfield was a compensation case. The first cases on the constitutionality of workmen's compensation, Southern Pacific Company $v$. Jensen, ${ }^{43}$ and the Winfield case were decided in that term. The compulsory compensation statute of New York, the Court said, was constitutional, ${ }^{44}$ the voluntary pressure program of Iowa was good, ${ }^{45}$ and so was the compulsory class insurance compensation scheme of Washington. ${ }^{46}$ But the Court said in the Jensen case that a state compensation program could not be devised for longshoremen, and in Winfield that a state program could not be extended to cover railroad workmen who were engaged in interstate commerce when they were hurt. Because there was no case for fault, the workman in Winfield was without a remedy although he lost the sight of an eye while he was on the job. Most of the sting has been removed from Jensen. There is a federal compensation act now for longshoremen and harbor workers, ${ }^{47}$ and the difficulties in allocating the right man to the right program, federal or state, where there is the possibility of doubt, have been resolved by the Court in Davis v. Department of Labor. ${ }^{48}$ The decision of any agency, federal or state, on classification in the overlapping area, the Court said, will be taken as conclusive. But Winfield looms larger now than before 1939. Perhaps it is worth remembering that the New York Court of Appeals was reversed in Winfield and that a powerful dissent was written by Mr. Justice Brandeis.

It is worth repeating that the effects of $W$ infield were not all bad before I939. ${ }^{40}$ The Court had decided that the regulating of railroad workmen under the Federal Act was exclusive in its area. Congress had no reason to prescribe so expressly in Igo8 because state compensation laws were not then on the statute books. With its decision in the Winfield case and its tight transportation test, the Court was building a relatively restricted area within which the Federal Act could be exclusive. Percentagewise the effect was not great, but in specific instances the results were important. If a railroad workman was not covered under the Federal Act because

\footnotetext{
to persons who had to stand across the boiler top); Anderson v. Atchison, T. \& S. F. Ry., 3I Cal. 2d I17, 187 P. 2 d 729 (1947), rev'd, 333 U. S. 82I (1947) (company obliged to search for a conductor reported missing).

${ }^{43} 244$ U. S. 205 (1917).

"New York Central R. R. v. White, 243 U. S. 188 (1917).

45 Hawkins v. Bleakly, 243 U. S. 2 Io (I9r7).

${ }^{40}$ Mountain Timber Co. v. Washington, 243 U. S. 219 (19I7) (four judges dissenting without opinions after counsel had attacked the state-administered insurance scheme).

${ }^{7}$ Enacted in 1927. 44 STAT. 1424. See 33 U. S. C. $\$ 901$ et seq. (1946).

18 314 U. S. 244 (194I).

10 See Miller, Workmen's Compensation for Railroad Employees, 2 Loyola L. Rev, 138, 152 (1944). Compare the discussion in footnote 22 supra.
} 
of the transportation test and the pinpoint rule, he could be covered under a state program. In some instances the legislatures had set up state liability programs for railroad workers, and under some local compensation statutes railroad employees were excluded expressly from the compensation scheme..$^{50}$ Nevertheless in a substantial number of states some injured railroad workmen could get compensation benefits. ${ }^{51}$ With instances of cases like Chicago \& Northwestern Railway $v$. $B^{B} l l e^{52}$ added to the picture, some cases were falling to the compensation programs.

It is the principal thesis of this paper that there is no reason to conclude that Congress tried to affect the compensation area in 1939 or to extend the doctrine of the Winfield case. The scope of the statute now is so comprehensive that there are few railroad employees who are not covered by it. ${ }^{53}$ If any employee does anything as a part of his daily routine pertaining to interstate commerce under the expanded definition, he can process his case under the federal statute no matter what he was doing when he was hurt. Of course his injury must have been derived from something incidental to his job. ${ }^{54}$ The word "can" is the nub of the proposition. If he "can" process his case, does it follow necessarily that he "must" do it? That is what the great majority of judges have said, and they charge their conclusions to the theme of the Winfield case. ${ }^{55}$ We do not propose here to examine all the criticisms against FELA and workmen's compensation, or to consider the kinds of remedial programs that have been offered as substitutes for the federal scheme. $^{58}$ We are supposing for our problem that we must work with case law

${ }^{50}$ See the tabulation in the Railroad Retirement Board Strvey on page 28 .

${ }^{61}$ You think of the states where you have lived. In Minnesota there was a state employers' liability act, with its remedial tort scheme for railroad workers comparable to the program of the Federal Act. See Minn. Laws 1915, c. 187, as amended, Minn. Laws 1923, c. 133, Minn. Laws 1951 c. 51; cf. MINN. STAT. $1949 \$ \$ 219.77-219.83$. In Louisiana railroaders could be covered under state compensation. See Fluitt v. New Orleans T. M. Ry., 187 La. 87, 74 So. 163 (1937). It was so in Wisconsin [cf. Kettner v. Industrial Comm. 258 Wis. $615,46 \mathrm{~N}$. W. $2 \mathrm{~d} 833$ (I95I)] and in California [cf. McKinney v. Industrial Acc. Comm., I37 Cal. App. 206, 30 P. 2d 78 (1934)].

${ }_{22} 284$ U. S. 74 (I93I). The plaintiff lost a case where the record was sufficient for fault. When he was hurt he was not engaged in transportation or something so closely related to it as to be within the definition of the Shanks case. Under the Illinois case law he could have processed a claim for compensation. By the time that final judgment was entered against him in the tort case, it could have been too late for him to ask for compensation. The Supreme Court has been generous about the tolling of the statutory limitations in the Federal Act when a plaintiff has asked first for compensation. See McCabe v. Boston Terminal Co., 309 U. S. 624 (I940), reversing, 303 Mass. 450, 22 N. E. 2 d 33 (r939).

${ }^{5}$ Some of the judges who have wanted to save some of the old area of compensation have been willing to sacrifice part of the remedial scheme of r939. Cf. Baird v. New York Cent. R. R., 274 App. Div. 577, 86 N. Y. S. 2d 54 (3d Dep't 1948), rev'd, 299 N. X. 213, 86 N. E. 2d 567 (1949). There the court tried to save a compensation claim by effecting a tight interpretation of the newer definition of interstate commerce. It has been obvious to most judges that Congress intended the definition to be administered generously. The Idaho court tried to save a compensation case by agreeing with the older cases that work on a new construction job was not in furtherance of interstate commerce. Moser v. Union Pac. R. R., 65 Ida. 479, $x_{47}$ P. $2 \mathrm{~d} 336$ (r944) discussed in note 20 , supra. If the courts can save some of the compensation benefits from the old regime, they must do it with some other kind of interpretation scheme.

this is hornbook law that is basic under any kind of work-injury program. Cf. Erie R. R. v. Winfield, 244 U. S. I70 (I9I7).

${ }^{65}$ See the cases cited in note I7, supra.

${ }^{6}$ See the Resolution enacted in the House of Delegates of the American Bar Association at St. Louis in 1949. 74 A. B. A. REP. I08 (1949). Cf. RRB SuRveY cc. ro, I1, 12; Pollack, Workmen's 
and with old-fashioned lawyer techniques on statutory interpretation, distinctions, and analyses. It is a small percentage kind of job at best, and it is not an adequate substitute for a comprehensive reappraisal, but it is important as a preliminary inquiry. Although the case quantity seems minute, the problem has been important to individuals in many instances. Some lawmen are not ready yet to resolve even small inequities by the law of averages.

Certainly we must reckon with the Winfield case and the power which Congress has to do exactly what the Court discovered in 19r7. But we are working in the area of statutory construction, and in that area we do not follow precedent blindly or forever. ${ }^{57}$ It is true that there have been many opportunities for Congress to attack the theme of Winfield either to clinch it, to disavow it, or to afford to state agencies some choice about it. By precise text Congress has not effected any change. Nevertheless, the whole scheme of the I939 revision is remedial in plan. If we are so impressed by time and silence in our approach to the Winfield case as to conclude that it is one which the Court cannot now disregard, it is arguable that the Court can tie Winfield to the case law of the old era. The few instances that may slip through to workmen's compensation will not be many, nor will the totality of compensation awards be much in dollars and cents, but an award in compensation can mean much to a claimant like the workman in Southern Pacific Company v. Industrial Accident Commission, ${ }^{58}$ a California case. The claimant was a car repairman who was trying to remove an iron hinge from the door of a work car, when he was hurt. In pulling and tugging at the hinge he disengaged a sliver of metal which struck him in the eye, and he lost the sight of the eye. To attempt to solve this kind of case with fault, safe-place, and inadequate-tool doctrines smacks of ritual and incantation. It is enough to say that the man in the California case was without a remedy because the court was Winfield conscious, although a workman like the injured claimant would have been entitled to compensation in California before $1939 .{ }^{59}$ There are other cases like it, enough of them that lawyers

Compensation for Railroad Work Injtries and Diseases, 36 CORNELL L. Q. 236, 27I (195I); Richter and Forer, Federal Employers' Liability Act-A Real Compensatory Law for Railroad Workers, 36 CoRNelL L. Q. 203, 205 (195I); Miller, Workmen's Compensation for Railroad Employees, 2 Loyola L. REv. I38, $16 \mathrm{r}-\mathrm{r} 62$ (r944).

${ }^{67}$ Even in the highest English Court, the Lords recognize that they are not bound by precedent on statutory interpretation. Cf. Harris v. Associated Portland Cement Manufacturers, [1939] A. C. $7 \mathrm{r}$.

${ }^{68}$ Southern Pac. Co. v. Industrial Acc. Comm., r9 Cal. $2 \mathrm{~d}$ 27x, 120 P. 2d 880 (I942).

${ }^{60}$ See McKinney v. Industrial Acc. Comm., $x_{37}$ Cal. App. 206, 30 P. 2d 78 (1934). But cf. Northwestern Pac. R. R. v. Industrial Acc. Comm., 73 Cal. App. 2d 307, 166 P. 2d 334 (1946). In the latter case deceased was a brakeman assigned to service on interstate trains. He was killed in a collision with another automobile while he was riding to work in a taxicab furnished by his employer. The accident occurred before r939. The cab was used because other means of public transportation were not available and the occasion pertained to his employment. But the pinpoint rule did not control the case. When a railroad man is engaged in both kinds of work and is killed when he approaches the yards or the office, the interstate possibilities are dominant. That proposition was derived from the other Winfield case. Erie R. R. v. Winficld, 244 U. S. 170, I73 (I917). The Winfields in the two cases were not related to each other. Their employers were different and there was no connection between the events in the two cases. The proposition of the other Winfield case when applied to the facts in the California case left the plaintiff without a remedy. No tort could be charged to the carrier, and no compensation could be awarded under the old case law. 
should be ready to reappraise Winfield and to think of statutory interpretation as a part of a remedial program. ${ }^{60}$

The Illinois Supreme Court is the only one committed squarely to the proposition that Congress in 1939 did not try to block the states' affording compensation to railroad workmen engaged in local work." Obviously "local," "intrastate," or "interstate" within the definition of a statute are not simple descriptive words. They do suggest litigation, and they suggest the necessity for inquiries and appraisals. According to Winfield when a case fits the pinpoint transportation test of the old case law, there is no choice; the plaintiff sues in tort under the federal statute, or he has no claim for anything. And we cannot argue that Congress has disavowed that proposition. There were work injury cases before $x 939$ when railroad men were remediless at law. In some states, as we have seen, the legislatures had concluded that overlapping was so probable and so difficult to adjust that railroad men should be excluded from the compensation field. ${ }^{62}$ We concede that we are talking about few instances and small percentages. We argue that workmen's compensation is good, even as it is today, and we point to the Illinois case as supporting our thesis that Congress did not intend to touch in 1939 what had been gained, perhaps inadvertently, through workmen's compensation.

Under the scheme of the Federal Act the workman in the Illinois case could have qualified as a plaintiff in a suit for damages. He was a freight-yard watchman who was attacked by thugs when he was trying to arrest a trespasser. Some of the jobs that workmen like him do pertain to the furthering of interstate commerce. But he was not engaged in interstate commerce at the time that he was hurt, even under the extended definition of the Act. Under such circumstances the Illinois court said that Congress cannot make the federal scheme effective to control a claimant's case. It was a case of local interest, the court said, which can be regulated only through state action. The thesis of the opinion is too sweeping. It is not arguable now that Congress cannot control this kind of case exclusively, but it is arguable that Congress has not chosen to do it, and that concurrent regulation is a possibility for legislators and administrators to consider. In other instances like it, plaintiffs have recovered damages under the Federal Act when they have argued from a record that a company had failed to afford adequate police protection for an employee's safety. ${ }^{63}$ The Supreme Court has not held that in this narrow area there cannot be concurrent regulation. The Court denied a petition for a writ of certiorari to the Illinois Supreme Court. ${ }^{64}$ It is true that petitions for writs have been denied in the other cases, also, where local courts have felt helpless before

\footnotetext{
${ }^{60}$ All of the cases cited in note 17 , supra, are instances where workmen had suffered injurics arising out of and happening during their employment and where compensation was refused for reasons like those offered in the California case.

${ }^{o 1}$ Thomson v. Industrial Comm., 380 Ill. 386,44 N. E. 2d I9 (1942).

${ }^{62}$ RRB SURver 28 . See the discussion in note 51 , stipra.

${ }^{63}$ Lillie v. Thompson, 332 U. S. 459 (I947) (deciding, on demurrer, that plaintiff had stated a cause of action); Lillie v. Thompson, I73 F. $2 \mathrm{~d}{ }_{4} 8 \mathrm{I}$ (6th Cir. 1949) (remanded to trial judge to enter judgment on the plaintiff's verdict).

os Thomcon v. Industrial Commission, 318 U. S. 755 (1943).
} 
the arguments of carriers derived from the expanded Federal Act and the thesis of the Winfield case. ${ }^{65}$ It can be argued that this denying of writs indicates that local judges do have some choice about the effect of Winfield after 1939.

If we must accept Winfield as spelling out some area of limitation on state action, and if we argue from the scheme of the 1939 revision that Winfield must be tied to the occasions that produced it, two alternatives are probable. There can be state as well as federal regulation in all the area of railroading outside the instances of transportation, or there can be state as well as federal regulation only when the instances occur outside the area defined as interstate within the newer statutory definitions. Under either approach we are inviting litigation over distinctions that can be artificial. Unless we accept the first alternative, however, we are letting Winfield and the statutory changes affect the old area of compensation.

There is merit certainly in Mr. Justice Brandeis' criticism of the Winfield decision. ${ }^{60}$ Even in 1917 he would have let any injured railroader choose to litigate his case for fault or to file a claim for compensation. But there is an argument against the Brandeis thesis. Employers must be protected against crippling costs. Standardized compensation and extended liability are two ends of one remedial stick. ${ }^{67}$ There is another argument against the Brandeis thesis, one that is perhaps more legalistic. Time and silence are on the side of $W$ infield as a potent limitation. If Winfield is pinned down to the case law of the old era, there will be overlapping of statutory regulations, and there will be an area where absolute liability will not be conditioned by limitations on the amounts recoverable, but the area will be minute, the cases few, and the costs trivial. The one good result from the old era can be preserved, and some few claimants can be protected. That the costs of litigation over hair-splitting distinctions can outweigh the advantages in preserving something good from the old regime is a probability that can be resolved only through the attitudes and understanding of the judges. That judges can respond to resolve probabilities like these is illustrated in the story of the Jensen case.

The Winfield case is published in the same volume of reports as the opinion in the Jensen case. ${ }^{68}$ In that case the Court held that longshoremen were beyond the reach of state legislatures with compensation programs. In other cases following Jensen harbor workers were added to the protected class. ${ }^{69}$ Congress did step in thereafter to afford a comprehensive compensation program for both longshoremen and harbor workers. ${ }^{\text {i0 }}$ Perhaps it is easy to describe a longshoreman but it is not easy to describe the kind of harbor worker that a state legislature cannot touch. ${ }^{71}$

${ }^{\circ \sigma}$ Trucco v. Erie R. R., 328 U. S. 843 (r946); Albright v. Pennsylvania Co., 323 U. S. 735 (x944).

${ }^{00} 244$ U. S. 154 et seq.

${ }^{07}$ See Pitney, J., in New York Cent. R. R. v. White, 243 U. S. 188, 202-204 (1917).

${ }^{\circ 8}$ Winfield: 244 U. S. 147 ; Jensen: 244 U. S. 205 . In fact, the decisions were handed down on the same day.

${ }^{80}$ The word "protected" includes a touch of sarcasm. See Baizley Iron Works v. Span, 28I U. S. 222 (1930); Gonsalves v. Morse Dry Docks \& Repair Co., 266 U. S. 17 (I924).

${ }^{70}$ The Longshoremen's and Harbor Workers' Compensation Act, 44 STAT. r424 (1927), 33 U. S. C. \$gor et. seq. (1946).

${ }^{71}$ See Parker v. Motor Boat Sales, 314 U. S. 244 (194I). In spite of the cases referred to in note 
In some instances the person who can qualify as one is engaged by an employer who contributes to a state fund or carries insurance protection under a state program and who discovers only at the time of the event that his workman was engaged in navigation. Supposedly the problem must be solved by one answer. At the time of his injury the man was a harbor worker and subject only to the federal compensation scheme, or he was some other kind of worker whose claim must be processed under a state act. The distinctions are fine, and the decisions are administrative. In the Davis case the Supreme Court has recognized the possibility of concurrent control in these situations by allowing the agency, federal or state, under which a claim is first processed, to effect a final classification which will not be reviewed. ${ }^{72}$ The Court has admitted that the effect of this decision is to afford a kind of double regulation.

There are some other cases which support the thesis of this paper. The South Carolina Supreme Court has been just as positive as the Illinois court in stating its case against exclusive regulation. ${ }^{73}$ The judgment in the South Carolina case was trivial in amount, but the language of the court was definite in tone. The plaintiff was a railroad workman who had strained his back while he was piling bales of cotton on a railroad platform. The cotton was a part of an intrastate shipment, but this workman did handle interstate shipments also. Under the State Employers' Liability Act in this kind of case, the defense of contributory negligence was not effective even to cut down compensation. Although the plaintiff had tackled the job by himself when he should have known that he was not equal to the task, the carrier should have known that other workmen would be needed. The plaintiff sued under the state act, and judgment in his favor was affirmed in the state supreme court. The court conceded that federal regulation could be effective here, but the court said it was not exclusive. "No one questions that Congress has the power to regulate interstate commerce, and it may preempt the field, but as before indicated, we do not regard the 1939 amendment to the Federal Employers' Liability Act as excluding all state law on the subject."

There are some instances where a railroad workman's case affects another carrier than the one who pays his wages. The Federal Act covers employment relations between carriers and their employees. The courts have said that "employer" means conventional employer. ${ }^{75}$ Sometimes two carriers can qualify as conventional

69 supra, there was a trend in the case law toward recognizing a doctrine of local concern. The effect of this was to permit many kinds of harbor workers to be covered under state compensation laws. See Miller's Underwriters v. Braud, 270 U. S. 59 (1926); Carlin Construction Company v. Heaney, 299 U. S. $4 \mathrm{I}$ (1936). As soon as Congress required compensation protection for harbor workers who were not covered under state acts, courts began to effect an expansive interpretation in the other direction. That trend is pointed up in the Parker case.

${ }^{72}$ Davis v. Department of Labor, 317 U. S. 249 (1942); cf. Occidental Ind. Co. v. Industrial Acc. Comm., 24 Cal. 2d 310, I49 P. 2d 84I (1949) (where the state court reversed an award of the local commission in favor of a local claimant who was not a harbor worker but a seaman fisherman entitled to maintenance and cure).

${ }^{73}$ Boyleston v. Southern Ry., 211 S. C. 232,44 S. E. $2 d 437$ (ז947).

"7I 2 I S. C. at 242,44 S. E. 2 d at 541 .

${ }^{75}$ Latsko v. National Carloading Corp., I92 F. 2d 905 (6th Cir. I95I); Gauldin v. Southern Pac. 
employers because they share wage-paying and time-using, ${ }^{76}$ but there are other instances where the conventional employer status is derived from the measure of a local statute. In a Missouri case the injured workman was employed by the Terminal Association in St. Louis which had leased certain of its facilities for use by the Frisco Lines. ${ }^{77}$ The tortfeasors were employed by Frisco, and the injured plaintiff was hurt in the line of duty. The case was processed against both carriers under the federal statute. Although the plaintiff could not reach Frisco for the claim because that carrier was not the conventional one, he did reduce his claim to judgment for the tort against the Terminal Association. The court found the measure of the conventional employer's responsibility in a local statute under which a lessor railroad must respond for a lessee's torts. In an Illinois case where an engineer was employed by Gulf, Mobile \& Ohio and was injured by the tort of the Terminal's men, judgments were recovered by the engineer against both carriers. ${ }^{78}$ The Illinois court justified the double obligation by referring to a local statute like the Missouri one.

As recently as 1949 the New York Court of Appeals agreed with the many judges and said that Congress did reduce the compensation possibilities in $1939 .^{79}$ Nevertheless in 1952 that court protected a state compensation claim against a railroad carrier's attack and did it under an old state statute that was enacted before I939. ${ }^{80}$ The employer had paid compensation to the workman during a four-year period. After the employee died, his widow claimed compensation for the final two weeks. The carrier resisted the widow's claim and argued that the case was one which was covered exclusively under the Federal Act and that the award should never have been made in the first place. The court did not permit an inquiry into the merit of the argument. Under the state law an employer can waive its federal rights. It is significant that there had been no argument on this proposition before the state board and that the court saw no repugnance between the effect of this statute and the exclusiveness of the federal program. ${ }^{81}$

Co., 78 F. Supp. 65I (N. D. Calif. 1948). Cf. Terminal R. R. Assoc. v. Fitzjohn, I65 F. 2d 473 (8th Cir. I948), I A. L. R. 2d 290 (1948): The injured crewman was not on the carrier's payroll Although he worked in an industrial plant, he was in the company's employ. Originally he was procured through the company's personnel office and he retained his seniority on the carrier's employment roll. As an employer the railroad was responsible for the unsafe conditions in the plant.

${ }^{70}$ Lavender v. Kurn, 327 U. S. 645 (1946).

${ }^{77}$ Graham v. Thompson, 212 S. W. 2d 770 (Mo. 1948).

${ }^{78}$ Wilson v. Terminal R. R. Association, 333 Ill. App. 256,77 N. E. 2 d 429 (x948).

${ }^{70}$ Baird v. New York Cent. R. R., 299 N. Y. 213, 86 N. E. 2d 567 (I949).

${ }^{80}$ Ahern v. South Buffalo Ry., 303 N. Y. 545 , I04 N. E. 2d 898 (I952); of. Heagney v. Brooklyn Eastern Dist. Terminal, x90 F. 2d 976 (2d Cir. $195 \mathrm{I}$ ). The claimant in the latter case was barred from suing under the Federal Act because he had processed his claim for compensation and had accepted a weekly stipend. The federal court found a waiver here comparable to a settlement of the claim. But see Pritt v. West Virginia Northern R. R., 132 W. Va. 184, 5r S. E. 2d 105 (r948), cert. denied, 336 U. S. $96 \mathrm{I}$ (1949). In the West Virginia case compensation had been awarded but the action of the local administrators had not been confirmed by judicial action. In West Virginia there was no statute like the New York one, and the plaintiff was not barred.

${ }^{81}$ There may be other isolated instances where state law measures have been used in the exclusive regulation area. One possibility is illustrated in Mooney v. Terminal R. R. Association of St. Louis [352 Mo. 245, $176 \mathrm{~S}$. W. $2 \mathrm{~d} 605$ (1944)]. It was argued in the Mooney case that discoverable peril 
The weight of the case law against the thesis of this paper is heavier in 1953 than it was ten years ago, but the thesis is not old enough yet to be obsolete. It can be summarized again in a few sentences. With the tight transportation test, the pinpoint rule, and the exclusive regulation doctrine of the Winfield case, the Supreme Court opened a small compensation area to the employees of interstate railroads. Congress did not restrict that area literally in the act of 1939. Although there was merit in Mr. Justice Brandeis' argument against the Court's exclusive regulation doctrine, the case in favor of the doctrine has depended on cost factors. If railroads have to carry two kinds of work injury programs for most of their employees, the costs of both could be unreasonable. Nevertheless, in 1939 Congress did not literally confirm, or restrict, or modify the doctrine of the Winfield case. Nor did Congress consider the probability of concurrent programs in any area, but Congress did plan a series of changes to extend the remedial protection of the Federal Act to more railroad personnel. Statutory interpretation demands adjustments which depend on many factors. Because Congress did not meet the issue squarely, and because the plan of the 1939 statute is expansive, it is arguable that exclusive regulation can be confined to the area carved out before I939. Under this interpretation there will be concurrent regulation in a small area affecting a few railroad workmen. Within that area a railroad company will have to carry the costs of two kinds of work injury programs, but the cost burdens will be negligible. It is apparent that there is in this the probability of litigation, depending on inquiries and classifications, but there was that probability before 1939, and there has been some of it under the one-sided case law since 1939. That the probability can be reduced, if the courts choose to do it, is illustrated in the Davis case.

The argument of this paper is important for what it is, a proposal for solving a few hard cases, but it serves a function that is even more vital. That the questionable area exists at all illustrates the inadequacies of the Federal Act as a scheme of social legislation. Ours is not an ideal world. We do not try to measure the good of a socal welfare program only by the ideals of a Christian kind of charity. As we plan for social living in this world, we cannot always escape from history or self-interest. Nevertheless we can try to reach for the common good and to understand what it means for men to share social costs and benefits.

Although there are lawmen nowadays who tell us otherwise, two propositions are fundamental. The fault concept in personal injury cases is obsolete, and there is no such actuality as an adequate award. ${ }^{82}$ Men cannot help themselves alone. They share privileges, responsibilities, and functions in an industrial society, and they share also its risks and burdens. Most of the burdens from physical hurts are absorbed by injured persons and their families. Tort costs are shared with tort-

and last clear chance are different doctrines, that one is state and the other federal, and that the judge had permitted the jury to use the state measure in the Federal-Act case. That part of the trial judge's disposition was approved although a judgment for the plaintiff was reversed on other grounds. The problem was relatively academic because under the federal statute contributory negligence can affect only the amount of damages and the jury must effect the adjustment.

${ }^{82}$ Good lawyers have done much to popularize the phrase "adequate award." Sce Belli, The Adequate Award, 39 Calif. L. Rev. I (195I). 
feasors, employers, and insurers. Even when judgments are large some cost burdens must be absorbed by community neighbors. ${ }^{83}$ Perhaps this kind of burden sharing cannot be translated into cost items in a casualty or compensation statistical report, but it does exist. Whether we like it or not, we have to live with social burdens derived from torts, even though we suppose naively that only the parties to a lawsuit are affected by the outcome, and then only as they have contributed to the events.

Reaching for alternatives to fault in the casualty field is a task lawmen must measure up to someday. The impossibilities, the second guessing, and the cruelties of the fault thesis are tempered practically by doctrines like respondeat superior and res ipsa loquitur, and by conditions like insurance risk-shifting and adminstrative measuring through the jury system. Perhaps we shall continue for many years to get along with the fictions and incongruities in this field, because alternatives are so difficult to plan and because the conditioning factors produce results that are more or less acceptable. There is, however, a practicable alternative in the workinjury field. ${ }^{84}$ Figures and statistics notwithstanding, the case for workmen's compensation is sound. The figures and compilations suggest that compensation as we know it today may be inadequate and administration too costly. Perhaps we can learn through these statistics that litigation-type contests have no place in the administering of workmen's compensation and that common-law analogies are not helpful for compensation lawyers, but social insurance is with us for good, and lawyers must make the best of it.

We are still supposing that legislators function in the twentieth century as they did in the early eighteen hundreds, when men from many levels of life attended legislative sessions to prescribe for all of the affairs of state. Practically we know that legislators confirm often what special interest groups propose as good. Nor is that necessarily bad. Dentists, for example-and to present a wholesome illustration -should know what the standards ought to be for men in their profession. Lobbying by dentists for professional regulation is a sound routine. ${ }^{85}$ Perhaps there is reason to suppose that sometime law-making schemes like code drafting under the old National Recovery Act may be an everyday device. Nevertheless it is sufficient here to say that we are not ready yet for industry-council kind of lawmaking and that Congress does not have to abdicate its functions when it accepts from railroad men the suggestions for a plan of compensation. The framework of the plan must come from people who are in the business-from workmen, clerks, executives, stockholders, and railroad lawyers. Members of the legal profession are important persons in their communities. Their advice is essential in the drafting of social legislation, but they must serve as counselors and not as advocates.

\footnotetext{
${ }^{83}$ We are not thinking here only of increased costs through bigger insurance premiums. The costsharing possibilities are more indirect and more expensive.

8* Some persons have seen possibilities for it in the automobile field. Compensation for Automobile Accidents: A Symposium, 32 Col. L. Rev. 785 (1932); Comment, 3 Law \& Contemp. Prob. 579 (1936). Cf. Saskatchewan's Automobile Accident Insurance Act of 1947 (c. 15) as amended in r948 (c. 15 ) and in 1949 (c. Ir), discussed by J. Green in $3 \mathrm{I}$ J. Coxrp. LEG. \& INT'I L. (3d Ser., Pts. III and IV) 39 ( 1949 ).

${ }_{80}$ There is one such statute I know well and which I think is sound. Louisiana Acts r940, No. 334 . LA. REv. STAT. $\$ \$ 37: 752-790$ (I950).
} 


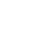

